\title{
Mezi Bohem a církví - pluralizace náboženské zkušenosti v římskokatolické církvi ${ }^{1}$
}

\author{
Between God and Church - The Pluralisation of Religious \\ Experience in the Roman Catholic Church
}

\author{
Michaela Bartošová
}

\begin{abstract}
The results of this qualitative research, which has used the method of grounded theory, show how the privatization of religious experience can be found within church organizations, particularly in this case study of eight young people who regard themselves as active members of the Roman Catholic Church. All the respondents lived under similar conditions as the research was being conducted: they were financially self-sufficient, still unmarried and they were living on their own, without a partner. Three ideal types of believers were defined through qualitative, in-depth interviews with these people. These types are based on their attitude toward the church organization on the one hand and on their subjective faith on the other. In the first case it was subjective, intimate and individualized religious experience that determines the attitude of believers toward the church, including its rules and rituals. In the second case the subjective faith and churchmanship were inseparably integrated. In the case of the third type, personal religious experience was seen almost entirely as a result of internalized religious norms and the participation in church ceremony.
\end{abstract}

KEYWORDS individualization, privatization of religion, Roman Catholic Church, singles

Za jeden z hlavních projevů sekularizace náboženství je považována jeho privatizace dochází k posilování necírkevně orientované religiozity, ke snížení vlivu velkých náboženských organizací, hlavní roli začíná hrát osobní náboženská preference - subjektivní akt víry. Naproti tomu se však velké náboženské organizace, které v procesu modernizace a sekularizace společnosti postupně ztrácely své dřívější privilegované postavení, snaží v posledních desetiletích svou pozici znovu upevňovat, zasahovat do veřejného života, předkládat některé normy a hodnoty vycházející z jejich náboženské tradice jako obecně platné. V českém prostředí je proces tzv. deprivatizace patrný (mimo jiné) i na př́kladu římskokatolické církve, ke které se zde tradičně hlásí největší počet křest’anských věřících (Nešpor 2004).

Kvalitativní výzkum, ${ }^{2}$ jehož část v následujícím textu prezentuji, se orientoval právě na věřící mladé lidi, kteří se hlásí ke katolické církvi a považují se také za její aktivní příslušníky. Tito lidé byli zároveň singles - ekonomicky nezávislí, dosud nesezdaní a žijící sami, bez part-

Sociální studia. Fakulta sociálních studií Masarykovy univerzity, 3-4/2008. S. 85-102. ISSN 1214-813X.

1 Tato studie vznikla s podporou Ministerstva školství, mládeže, a tělovýchovy - výzkumný záměr „Reprodukce a integrace společnosti“ (MSM0021622408).

2 Výzkum byl realizován v roce 2005 jako součást magisterské diplomové práce. 
nera. Výzkumný problém se proto $\mathrm{v}$ prvních fázích výzkumu týkal více než víry především možné konfrontace životního stylu singles s jejich př́islušností ke katolické církvi. Jak se během analýzy ukázalo, hrála osobní víra a př́klon k církvi, či obojí, důležitou roli při vyrovnávání se se statusem single a obecněji také determinovala postoje k partnerským vztahům. Způsob, jakým bylo s náboženstvím a křest’anskou tradicí zacházeno a jak byla víra v životě zvýznamňována, se však u jednotlivých osob lišil. Následující text reflektuje výpovědi o víree, na jejichž základě byli věřící rozlišeni podle preference osobního vztahu s Bohem nebo př́slušnosti $\mathrm{k}$ církvi tak, jak se tato dichotomie jevila být v rozhovorech podstatná. Postoje zkoumaných osob k církvi, požadavky kladené na věřícího na jedné straně a osobní náboženská zkušenost na straně druhé ukazují, jakým způsobem může i uvnitř velké náboženské organizace docházet k privatizaci náboženství, jakými významy je náboženství naplňováno v př́ípadě větší či menší preference osobní náboženské zkušenosti nebo naopak uznání autority církevní organizace.

\section{Privatizované i deprivatizované náboženství}

Thomas Luckmann (1967) považuje privatizaci náboženství za postupný proces, který se dnes prosazuje jako důsledek globální transformace sociálního řádu a institucionální specializace náboženství. Umístění náboženství do speciálních, od ostatních oblastí společnosti oddělených náboženských institucí se projevilo plným rozvinutím protikladu mezi náboženstvím a společností. Zároveň došlo $\mathrm{k}$ transformaci náboženství do podoby čistě subjektivní a privátní záležitosti, což bylo umožněno vznikem specifického životního prostoru, takzvané sféry soukromí, které se institucionální kontrola přímo nedotýká, v níž jedinci naplňují potřebu osobní autonomie a konstruují vlastní individuální identitu.

Náboženská tolerance typická pro evropskou náboženskost vede k specificky modernímu náboženskému individualismu, díky kterému se i samotný koncept Boha stává stále více subjektivním. Podle Bruce (2002) ztrácí individualizované náboženství svůj sociální význam, jelikož pro osoby lišící se svým náboženským přesvědčením a názory je obtížné sjednotit se v konkrétní sociální akci. Tento typ náboženství je proto jen těžko reprodukovatelný - skrze subjektivizaci náboženské zkušenosti jsou oslabovány struktury věrohodnosti, na nichž závisí úspěch náboženské socializace další generace.

Potřeba „prostoru pro sebe“, ve kterém jsou systémy nejvyšší významnosti určovány individuálními zájmy, se však často neslučuje s př́islušností $\mathrm{k}$ oficiálnímu náboženskému modelu - $\mathrm{k}$ církvi. Náboženští experti jsou profesionálně motivováni $\mathrm{k}$ ochraňování statusu quo a předávání stabilního oficiálního modelu laikủm. $\mathrm{V}$ těchto podmínkách dochází $\mathrm{k}$ napětí mezi oficiálním modelem náboženství a jeho privatizovanou formou (Luckmann 1967).

Jednou z odpovědí velkých náboženských organizací na sekularizaci a privatizaci je podle některých autorů deprivatizace náboženství - snaha náboženských institucí a organizací odmítnout své marginalizované postavení a zasahovat do věcí veřejných. Jako svůj základní požadavek postulují tyto instituce podřízení státu a trhu mravním normativům, jež jsou odvozeny od náboženství (Casanova 1994). ${ }^{3}$ I v České republice je možné mluvit o určitém typu

3 Podobný názor zastává Gilles Kepel (1996), podle nějž od sedmdesátých let dochází v Americe i Evropě k rechristianizaci (rejudaizaci, reislamizaci). 
deprivatizace náboženství. ${ }^{4}$ Podle Nešpora (2004) se křest’anství vrátilo, podobně jako v jiných evropských zemích, do politiky a začalo hrát roli v rozhodovacích procesech parlamentních stran. Lužný (2005: 110-111) rozlišuje tři způsoby deprivatizace v ČR: 1. Náboženská mobilizace na obranu tradičního životního světa před různými zásahy státu a ekonomiky (například boj proti potratům); 2. Zpochybňování autonomie státu a trhu, které mají v diferenciované moderní společnosti tendenci rozvíjet vlastní normy bez ohledu na vnější tradici morální normy; 3. Odmítání individualistických moderních liberálních teorií, jež redukují společné dobro na součet individuálních voleb.

Proces deprivatizace náboženství přitom probíhá v českém kontextu na pozadí rozsáhlé sekularizace a privatizace náboženství. Současný převažující vztah českých občanů k náboženství lze slovy Grace Davie (1994) charakterizovat jako „víru bez přináležení“, tedy odmítání církevně organizovaných forem zbožnosti ve prospěch její privatizované formy (Hamplová 2000, Nešpor 2004, Tichý 2004).

\section{Způsoby identifikace s náboženstvím}

Oddělení víry od konkrétní náboženské komunity má podle francouzské socioložky Danièle Hervieu-Léger (1999, in Tichý 2006) pro náboženské organizace závažné důsledky: institucionální režim potvrzení víry skrze konformitu s autoritou je nahrazován autoatestací - vlastní jistotou jedince, komunitní validizací - umožněnou koherencí skupiny a vzájemnou validizací víry rovnocenných jedinců - kritériem je autenticita prožitku. Osobní víra jako věc každého jedince nemusí být nutně „přenesena dál“. Rodiče sami sebe přestávají vnímat jako garanty náboženské transmise, naopak ve výchově svých dětí zdůrazňují „,právo volby“ (nejen) jejich náboženského přesvědčení. Mezi mladými lidmi je pak oceňována autenticita věřícího, který hledá svou vlastní podobu víry, vlastní pravdu (Hervieu-Léger 1998, 2003).

Náboženskou identitu proto již nelze považovat za jednoduše zděděnou, ale naopak konstruovanou každým jedincem. V této souvislosti navrhla Hervieu-Léger (1998) koncept ,identifikačních trajektorií" (trajectory of identification), kterými jedinci konstruují vlastní socionáboženskou identitu. Tyto dráhy zahrnují veškeré obsahy víry: náboženskou praxi, žitý smysl přináležení $\mathrm{k}$ náboženství, způsoby rozumění světu a jeho dopady na konkrétní jednání v jednotlivých sférách života. Směr těchto trajektorií je určován dispozicemi, zájmy a aspiracemi jedince a zároveň závisí na objektivních - institucionálních, sociálních, ekonomických, politických a kulturních podmínkách, ve kterých jsou utvářeny. Pro pochopení procesů náboženské identifikace $\mathrm{v}$ kontextu modernity navrhuje autorka čtyři typické dimenze identifikace: 1) společenskou (komunální), 2) etickou, 3) kulturní a 4) emocionální. Společenská dimenze se vztahuje $\mathrm{k}$ formálnímu a praktickému přináležení $\mathrm{k}$ náboženství; týká se množiny znaků (sociálních a symbolických), které definují hranice určité náboženské skupiny a umožňují rozlišovat mezi „těmi, kdo jsou uvnitř““ a „těmi, kdo jsou venku“. Etická dimenze zahrnuje

4 Nešpor (2004) mluví o takové náboženské deprivatizaci, která sice není závažná ve srovnání s masovou deprivatizací a sociální desekularizací v zemích Třetího světa nebo USA, svůj význam však získává v porovnání se situací před a po roce 1989. Jde sice o pozvolnou, a proto někdy „neviditelnou“ deprivatizaci náboženství, nicméně pro specifický český kontext významnou. 
individuální přijetí hodnot dané náboženské tradice. Tato dimenze se stále častěji odděluje od předešlé společenské dimenze - hodnoty určité náboženské tradice mohou být respektovány i bez přináležení k náboženské komunitě. Kulturní dimenze obsahuje soubor kognitivních, symbolických a praktických prvků, které utvárí odkaz náboženské tradice (jsou to např́klad knihy, jejich interpretace, rituální praktiky, ideály a způsoby myšlení, oblékání ...) Poslední emocionální dimenze - zahrnuje emocionální zkušenosti spojené s identifikací, pocity společného „splynutí vědomí“, „zakoušení hloubky“ a podobně. Kombinace těchto dimenzí a jejich přijetí jedincem vytváří různé způsoby identifikace s náboženstvím.

Autorka aplikovala svoji koncepci identifikačních trajektorií na př́iklad křest’anského náboženství - konkrétně vycházela ze znalosti kontextu francouzského katolicismu. Následující „typy“ křest’anství chápe jako určité ideální orientační body, mezi kterými jedinci reálně konstruují vlastní náboženskou identitu. Jde o: 1) emocionální (emocionální a společenská dimenze), 2) patrimoniální (kulturní a společenská dimenze), 3) humanitární (emocionální a etická dimenze), 4) politické (společenská a etická dimenze), 5) humanistické (kulturní a etická dimenze) a 6) estetické (kulturní a emocionální dimenze) křest’anství.

\section{Životní styl singles a křesłaanský ideál rodiny}

V zemích západní Evropy a v USA dochází postupně, od 60. let 20. století, k rozsáhlé demografické změně, označované jako druhá demografická tranzice. Tato tranzice se vyznačuje logickým sledem následných fází, během kterých dochází k proměně jednotlivých demografických jevi̊ směrem $\mathrm{k}$ demografickému individualismu a modernismu (Van de Kaa 1987). ${ }^{5}$ Rozhodující úlohu sehrály hodnoty individualismu, důraz na sebenaplnění a seberealizaci jedince a na jeho práva (Rabušic 2001). V České republice se tyto změny začaly výrazněji prosazovat na pozadí obecné transformace společnosti po roce 1989.

Jedním z nejpatrnějších projevů změn v oblasti partnerského a rodinného chování je fenomén singles. ${ }^{6}$ Přestože již finančně nezávislí na rodičích, zůstávají mladí lidé sami, bez partnera, a odkládají závazky spojené s manželstvím a rodičovstvím do pozdějšího věku. Zatímco v zahraniční (západoevropské a americké) odborné literatuře je životní styl singles reflektován už dlouhou dobu, u nás je spíše opomíjen. Během jednoho ze vstupních výzkumů zaměřených na motivace a životní strategie singles v České republice vyšlo najevo, že velká část těch, kteří se považují za singles, ve skutečnosti tak docela sama není (Tomášek 2006). Existence alternativních vztahů, ${ }^{7}$ které nahrazují nebo dočasně suplují funkci tradičních vztahů, potvr-

5 Jde o posun: 1) od manželství k nesezdanému soužití, 2) od antikoncepce jako prostředku ochrany před nechtěným početím $\mathrm{k}$ antikoncepci, jež umožňuje sebenaplňující volbu, zda dítě mít a kdy ho mít, 3) od éry, kdy bylo dítě středobodem života rodičů, k období, kdy středobodem života je pár a jeho dítě a 4) od uniformních rodin a domácností k pluralitním formám rodin a domácností (Rabušic 2001: 178).

6 Anglický výraz single je možné nejobecněji přeložit jako jednotlivec. Tato kategorie proto může zahrnout všechny jedince, kteři žijí sami - bez partnera (rozvedené, ovdovělé, kněží a podobně). Toto označení se však nejčastěji používá pro mladé, dosud nesezdané a ekonomicky soběstačné jedince, kteří žijí bez partnera. 
dila obecnější trend, dlouhodobě se prosazující i v západních zemích (Bawin-Legross 2004, Heath a Cleaver 2003 a další). Tyto vztahy pravděpodobně lépe vyhovují životu v podmínkách obecně flexibilizujícího se pracovního trhu a korespondují s nutností být mobilní a kdykoliv připravený přizpůsobit se jeho změnám (Beck 1992). Zároveň jsou však důsledkem rozsáhlé změny hodnot ve sfére intimity a partnerských vztahů směrem k individualismu (viz například Giddens 1992, Beck a Beck-Gernsheim 1995).

Rodina jako základní životní hodnota je $\mathrm{v}$ postojích mladé generace pořád prrítomna (Kuchařová a Zamykalová 2000), zároveň je však její zakládání stále častěji odsouváno do pozdějších životních fází. Životní styl mladých singles, ve kterém není bezprostředně počítáno se založením rodiny, proto může být v oblasti partnerských vztahů otevřen i jiným, alternativním vztahům, jež k tomuto cíli nesměřují.

Katolická církev i ostatní křest’anské církve však bojují různými způsoby za zachování tradičního rodinného modelu a ve všech směrech podporují rodinu a reprodukci, často i negativním vyhraněním se vůči všem formám soužití nebo partnerského chování, které tomuto modelu odporují. Způsob života mladých křest’anů by tak měl vést k zakládání rodiny, jež je $\mathrm{v}$ církvi považována za jednu $\mathrm{z}$ primárních životních hodnot $-\mathrm{v}$ souvislosti $\mathrm{s}$ tím by pro ně měly být závazné pouze partnerské vztahy směřující k manželství.

Hlavní výzkumný zájem byl proto orientován na možnou konfrontaci životního stylu mladých singles s jejich př́slušností ke katolické církvi. Zajímalo mě, jak se v životě a postojích těchto lidí promítá na jednu stranu fakt nepřítomnosti partnera a na druhou stranu členství v autoritativní náboženské organizaci. ${ }^{8}$ Část analýzy, prezentovaná dále v textu, se podrobněji zabývá především náboženskými postoji a představami zkoumaných osob.

\section{Metodologická východiska}

Realizace výzkumu a také následná analýza vychází z pozic interpretativní sociologie. Tento sociologický směr je postaven na předpokladu, že sociální skutečnost není člověku jednoduše objektivně dána, ale je předmětem neustálé a nezbytné interpretace (Berger, Luckmann 1999). V souvislosti s tímto př́stupem mě zajímalo, jak věrící lidé každodenně interpretují svůj život z hlediska své víry - at' už prímo nebo na základě internalizovaných norem a př́kazů a obecně potom, jaký význam přisuzují náboženství ve svém životě. Když vezmeme v úvahu Bergerovo (1967) pojetí náboženství jako interpretačního rámce skutečnosti, pak je právě u věřících možné předpokládat, že se náboženství velkou měrou podílí na interpretaci a chápání ostatních, ne-náboženských aspektů života. ${ }^{9}$ Výzkum se orientuje na věřícího jedince a jeho způsob sepětí s křest’anstvím a normami rrímskokatolické církve. Zajímají

rakteristické formy alternativních vztahů: 1) ženatí milenci a milenky, 2) 'víkendová manželství', 'apart but together', 3) distanční vztahy a 'nárazovky', 4) otevřené vztahy, 5) přítel/přítelkyně do nepohody, 6) 'hra na dokazování si'.

8 Více k problematice verrících singles a jejich životního stylu viz Bartošová (2006).

9 Vlivem sekularizace náboženství však může stejně tak docházet ke stavu tzv. kompartmentalizace, kdy je náboženství oddělováno od ostatních sfér nejen v rovině institucí, ale i v individuální mysli. Náboženství se i na úrovni jedince stává pouze jednou z mnoha životních oblastí a neurčuje jednání v ostatních sférách (Dobbelaere 1999). 
mě v této souvislosti otázky: Jakým způsobem se jednotliví věřící identifikují s křest’anstvím? Co pro ně znamená víra (jak ji definují) a jak ji z hlediska své víry vztahují k jiným oblastem svého života? Vyskytuje se u věřících katolíků potřeba privatizace náboženství nebo individuální interpretace křest’anského učení?

Kvalitativní výzkum probíhal podle pravidel zakotvené, empiricky podložené teorie, která věrně odpovídá zkoumané oblasti a vysvětluje ji (Strauss, Corbin 1998, 1999). Nástrojem sběru dat byly nestandardizované rozhovory, vedené podle předem připraveného „scénáře“, rozčleněného do několika tematických segmentů. ${ }^{10}$ Rozhovory byly se souhlasem konverzačních partnerů a partnerek nahrány na diktafon, doslovně přepsány a analyzovány s pomocí programu Atlas.ti. Komunikační partneři a partnerky byli vybíráni metodou sněhové koule nebo hledáni přes internetové seznamovací agentury. ${ }^{11}$ Do výzkumu bylo zahrnuto celkem osm osob, čtyři muži a čtyři ženy, ve věku od 25 do 31 let pracujících, ekonomicky soběstačných, dosud nesezdaných, žijících samostatně, bez partnera. Čtyři z nich měli vysokoškolské vzdělání, tř̌i středoškolské, jeden komunikační partner byl vyučen. Tito mladí lidé se zároveň považovali za věřící katolíky, kteří se pravidelně a aktivně účastní náboženských rituálů církve. ${ }^{12}$

Otázky po smyslu a definici víry se jevily být často obtížně zodpověditelné. Pro konverzační partnery a partnerky bylo mnohdy složité přenést náboženskou zkušenost do slov a blíže ji specifikovat. V prvních rozhovorech se jako významná součást víry ukázal být osobní vztah $\mathrm{k}$ Bohu, na který jsem se posléze ptala i v dalších rozhovorech, pokud o tomto tématu nezačali věřící mluvit sami. Nejen z výpovědí o víře však bylo zřejmé, v jakých souvislostech konverzační partneři a partnerky o náboženství přemýšlejí a jaký význam v životě mu přisuzují. Orientace výzkumu na dvě odlišné sféry - partnerské a rodinné vztahy na jednu stranu a náboženské představy a zkušenosti na stranu druhou - se ukázala být vhodnou metodou při zkoumání náboženské víry, která ve spojení s jinou oblastí života nabývala často konkrétní a praktické podoby.

Vzhledem k počtu provedených rozhovorů jde spíše o určitou sondu do problematiky privatizace náboženské zkušenosti v rámci deprivatizovaného náboženství, než o vyčerpávající studii. ${ }^{13}$

10 Celkem šlo o tři tematické celky: 1) minulé vztahy a partnerské zkušenosti, 2) náboženství a víra, 3) pojetí rodiny, partnerských vztahů a kariéry. Č́st týkající se víry a náboženství nebyla uvozena otázkou explicitně se vztahující k této oblasti; konverzační partneři byli pobídnuti k tomu, aby se pokusili říct, co je pro ně v životě nejdůležitější. Teprve poté, pokud o vírée nezačali mluvit sami, následovala otázka na smysl náboženství a víry v jejich životě a ve vztahu k dalším, nenáboženským sférám.

11 Konkrétně šlo o seznamku na křest’anských stránkách www.katolik.cz, na které jsem vložila inzerát se žádostí o rozhovor týkající se mého výzkumu.

12 V následující analýze vystupují všichni účastníci výzkumu v rámci anonymity pod přezdívkami, které si sami zvolili.

13 Př́spěvek na totéž téma vyšel také na stránkách Sociowebu (Tichý 2004). Privatizaci náboženství uvnitř katolické církve prezentoval autor mimo jiné na př́íkladu vztahu věřících $\mathrm{k}$ papeži Janu Pavlu II., který ač se snažil být politicky činnou osobou, pro samotné věřící se často stával pouze symbolem a celebritou, více než nezpochybnitelnou autoritou. 


\section{Vztah $\mathrm{k}$ církvi a Bohu jako dvě dimenze jedné víry}

Analýza rozhovorů ukázala, jakým způsobem se mladí křest’anští singles vyrovnávají s nepřítomností partnera ve svém životě a jak se jejich vnímání a pojímání náboženství podílí na vysvětlení jiných, nenáboženských sfér života, konkrétně partnerských vztahů a rodiny. Odmítnutí alternativních partnerských vztahů, které se ukázaly být pro mladé křest’any nepř́pustné, vedlo k jiným způsobům vyrovnávání se se samotou. Víra byla jedním z důležitých zdrojů adaptace na situace, které konverzační partneři a partnerky hodnotili jako obtížné či složité.

Společnou hodnotou všech oslovených osob ve výzkumu byla určitá základní úcta k člověku, což může plynout z jednoho ze zásadních křest’anských přikázání: „Miluj Boha a svého bližního jako sám sebe“. Jedna z komunikačních partnerek to chápala jako nepodmíněnou lásku k člověku, který je hodnotný už tím, že je, nikoli tím, jaké má vlastnosti nebo co v životě dokázal. Ve světle tohoto př́stupu je pak nahlíženo na ostatní jevy v životě. Kariéra a individuální zájmy by měly být vždy podřízeny zájmům „bližních“. V tomto konkrétním výzkumu, zaměřeném i na oblast partnerských a rodinných vztahů, se tato tendence projevila ve zvýšené potřebě odpovědnosti a závazku v partnerském vztahu, který by měl směřovat $\mathrm{k}$ dlouhodobosti a stálosti. Všichni dotázaní byli odhodlaní naplnit tento křest’anský ideál, i když si zároveň většina $\mathrm{z}$ nich byla vědoma vlastních mezí daných neschopností vzdát se zcela sám/sama sebe a obětovat vše vztahu a budování rodiny. Akceptace a sdílení určitých základních hodnot plynoucích z křest’anství odkazuje na etickou dimenzi identifikace s náboženstvím tak, jak ji konceptualizovala Hervieu-Léger (1998) a jež byla v oblasti partnerských vztahů nebo určitého, velmi obecného pohledu na svět přítomná ve výpovědích všech osob ve výzkumu.

Privatizace náboženství je na úrovni jedinců konceptualizovaná jako potřeba naplňovat své náboženské potřeby bez ohledu na vnější autoritu, pouze na základě vlastní volby a rozhodnutí (Luckmann 1967). U většiny oslovených se skutečně ukázala větší nebo menší potřeba distance od institucionální podoby náboženství a snaha vytvořit si paralelní autonomní prostor, ve kterém budou své náboženské potřeby naplňovat podle vlastního úsudku a zájmu, avšak $\mathrm{v}$ tomto př́ípadě zároveň vždy s ohledem na určující křest’anskou tradici. Z ní vyplývá, že je tento prostor určován především snahou dostat se blízko $\mathrm{k}$ Bohu, který stojí v jejím centru. Právě způsob, jakým je vztah k Bohu definován a naplňován, je onou „osobní volbou“, ze které plyne různé chápání toho, co je podstatné z náboženské tradice a co je obecně důležité $\mathrm{v}$ životě. Ne nutně musí stát vztah $\mathrm{k}$ Bohu v protikladu ke vztahu k církvi. Nicméně tak, jak se to ukázalo u některých věřících ve výzkumu, může právě výrazné upřednostňování a rozvíjení této dimenze víry vést ke střetu s církví a $\mathrm{k}$ individuálnímu výkladu náboženské zkušenosti. U jiných věřících, kteří neměli potřebu rozvíjet tuto dimenzi víry, se také neobjevila potřeba privatizovat vlastní náboženskou zkušenost.

Různé kombinace př́istupů k církvi a charakteru osobní náboženské zkušenosti identifikované ve výzkumu jsem v následujících podkapitolách rozlišila do tř́ ideálních typů věřících. Univerzalita katolické víry je na těchto prríkladech věŕících nahrazena pluralizací víry a rozdílným výkladem náboženské zkušenosti, plynoucím z více či méně individualizovaných náboženských představ. Vodítkem $\mathrm{k}$ pochopení těchto typů byly dimenze identifikace $\mathrm{s}$ náboženstvím vytvořené Hervieu-Léger a jejich použití na př́kladu křest’anství tak, jak byly předestřeny v úvodních kapitolách. 


\section{Bý† věrný Bohu a sám sobě}

Zejména ve výpovědích dvou konverzačních partnerek - Terezy a Jolany, se odrážela silná potřeba privatizovat vlastní náboženský prožitek, což může být dáno mimo jiné i vlivem prostředí a životního stylu, které podporují a umožňují individualizaci. Obě vystudovaly vysokou školu, Tereza pobývala během studií v zahraničí a obě o možnosti pracovního uplatnění v cizině vážně přemýšlí i do budoucnosti. Jolana žije prakticky třináct let mimo domov rodičů, takže přestože byla vychována v katolické rodině, již dlouho se pohybuje mimo tradiční vesnické prostředí, ve kterém vyrůstala. Tereza je konvertitka, která křest’anství přijala až v dospělosti. Obě žijí v současnosti ve velkém městě a je pro ně typická jistá míra prostorové mobility.

Konverzační partnerky opakovaně zdůrazňovaly potřebu vlastní nezávislosti (na rodičích, partnerovi, skupině nebo společenství) a požadavek určovat si vlastní životní dráhu. Jolana, která nikdy neprožila dlouhodobější partnerský vztah, vysvětlovala, v čem vidí výhody svého singlovství:

Přesto všechno, že je člověk sám, že je to taková samota, mi přijde, že si můžu dělat co chci a kdy chci - ale neznamená to, že můžu kdy chci tam nebo tam - ale spíš nemusím tak lpět na tom, co chci zrovna dělat - že mám prostor na rozmýšlení. Já jsem zvyklá být sama, nedovedu si představit být s někým, takže mně to přijde jako nejlepší stav, co mám. (Jolana)

I přes opakovaně zdůrazňovaný požadavek příliš se nevázat se však u Jolany projevovala i potřeba blízkých lidí a „významných druhých“. Singly (1999) tento rozpor charakterizuje jako kolísání mezi potřebou vzájemné závislosti a popřením této potřeby dané zdưrazňováním vlastního ,jác jako nejvyšší hodnoty v sociálním světě a zároveň požadavkem podpưrných sociálních struktur a blízkých vztahů. Vztah $\mathrm{k}$ Bohu a víra byla v jejím prrípadě určitou náhradou za vztah blízký - partnerský:

Vím, že jsem si vždycky říkala, že jsem přemýšlela o nějakých partnerech a říkala jsem si, to je hrůza, a jednu dobu jsem nikoho nechtěla jenom proto, že ten člověk by byl u mně vždycky až na druhém místě. To si myslím, že bylo tehdy, když jsem Boha jako partnera brala. (Jolana)

Spolu s tímto vztahem a přáteli je Jolana schopna rozvíjet sama sebe, upevňovat svou autonomii a hledat vlastní pocit štěstí a naplnění.

Vztah k Bohu a příslušnost k církvi pro obě konverzační partnerky neznamenají jistotu nebo jasný výklad světa a smyslu života. V otázkách víry se vyjadřovaly v termínech určitých obecných ideálů, jako je pravda, svoboda, láska a podobně. Bůh se v tomto kontextu jevil jako absolutní ideál - víra je cesta, která k tomuto ideálu vede a která je určována a stvrzována vnitřním pocitem naplnění, správnosti, rovnováhy sama se sebou:

Určitě je pro mě důležitá představa spásy, jako toho dostat se blízko jakémusi absolutnu - ideálu v nejčistším slova smyslu. Pro mě je to skutečně taková vlastní cesta směrem, který mám pocit, že tam směřuje. To mě zase zpětně naplňuje, když mám pocit, že jdu tou cestou. (Tereza)

V křest’anství obě vidí systém takových hodnot, který k tomuto ideálu vede. Spíš než o závazek vůči církvi nebo naplňování daných povinností a norem v něm spatřují určitý obecný morální apel. Obě konverzační partnerky jsou nějakým způsobem spojeny s církví, 
účastní se bohoslužeb, schází se s věřícími. Ve víře však byl pro ně rozhodující a podstatný vztah $\mathrm{k}$ Bohu a utváření vlastní cesty na základě tohoto vztahu. Církevní nařízení a pravidla přijímají, pokud je ony samy považují za podstatné pro svůj vlastní život a víru:

Ty tlaky existují, ale mně je to jedno - po nikom mně nic není... Mohou být tlaky, třeba at' se chodí každý týden do kostela, ale mně osobně to dělá dobře, že tam chodívám - nemusím tam jít třeba v neděli, můžu tam jít v úterý. Takhle třeba nemáš čas modlit se během dne a na mši si ho jednoduše vyhradíš. Pro mě je to hrozně důležité, protože jsem při tom ráda. Možná, že to nějak přeceňuju, že to dělá dobře mně a přitom se chovám podle nějakých norem, ale já vím, že ty normy byly, teprve až jsem si je osvojila. (Jolana)

Podle Davie (2004) je identifikace s náboženstvím ve formě přináležení k církvi stále více charakteristická nezávazností a jistým typem konzumerismu. Spojení s církví a návštěva bohoslužeb se stávají věcí osobní volby a naplněním určité spiše partikulární než obecné potřeby. Vazba jedince s náboženskou organizací probíhá pouze po dobu trvání tohoto osobního zájmu. Zejména u Jolany je ve vztahu k církvi patrný jistý typ „hledačství“ - postupně prošla několika různými katolickými společenstvími, ale svoji pozici v těchto skupinách hodnotila spíše jako „outsiderovství“ a setrvávala v nich pouze do chvíle, kdy se náboženské představy jiných lidí přestaly shodovat s jejími.

Tereza nejen v otázkách víry, ale i v jiných oblastech života odmítala nekritické přijímání cizích myšlenek. Tuto vlastnost spojila s výchovou svých rodičů-intelektuálů a s městským způsobem života, ve kterém vyrůstala, a zmínila ji také jako prríčinu rozpadu vztahu s minulým partnerem:

Když to hodně zjednoduším, tak jsem člověk, který vyrůstal v městském prostředí. U nás doma byl kladený důraz na intelektuální úroveň a je to pro mě důležité, uvědomuju si to. Třeba naše mamka mě od počátku vedla ke kritickému úsudku, aby si člověk mohl udělat svůj vlastní názor. Kdežto Vojta je z dědiny a na plno věcí si názor nepotřebuje dělat, takže v okamžiku, kdy jsem se s ním měla domlouvat, tak jsem ten názor měla a on ne... (Tereza)

Víra u těchto konverzačních partnerek nevede ani tak k potřebě zakoušení sounáležitosti s náboženskou skupinou nebo jinými věřícími, často spíš naopak, k pocitům jisté výlučnosti, způsobu odlišení se od ostatních nebo obecněji od určitých norem (daných jak církví, tak sekularizovanou společností1 $\left.{ }^{14}\right)$ :

Víra je něco, co mi v určitých chvílích může dát obrovskou míru svobody - můžu dělat věci, které nejsou obecně chápané jako běžné, správné. Křest'anství je založené na Kristu, který v podstatě většinu věcí, které dělal, tak bylo v očích normálních lidí strašná bláznivina, včetně toho, že pak šel na křriž a nechal se ukřrižovat. To mi dává pocit, legitimitu, že mohu dělat věci, které nejsou obecně chápané jako běžné. (Tereza)

14 Svoboda, o které Tereza v této souvislosti mluvila, znamenala především odvahu se odlišovat, a to jak od ideálu církevního, který spatřovala v orientaci na zakládání rodiny a usazení se, tak od hodnot sekularizovaného světa, chápaných jako nutnost získat výhodné a lukrativní postavení na pracovním trhu. 
V jejich pojetí si náboženství částečně zachovává podobu symbolického univerza, tak jak jej charakterizují Berger s Luckmannem (1999: 101): „Symbolické univerzum legitimizuje život jedince i celé společnosti v nejvyšší možné míře tím, že je zasazuje do sféry nadřazené každodenní lidské zkušenosti. Příklon k náboženství jako symbolickému univerzu vytváŕí a upevňuje osobní identitu člověka“. Osobní vztah k Bohu jako transcendentní entitě jim umožňoval umístit i jejich vlastní identitu do sféry transcendence, tedy primárně se vymezovat a definovat ve vztahu k Bohu. Jedinečnost této náboženské zkušenosti daná její individuální volbou a osobním (intimním, s ostatními lidmi nesdíleným) vztahem s Bohem však zároveň implikovala nejistotu, otřesitelnost tohoto vztahu a přeneseně také jejich (nejen náboženské) identity:

Víra mi přijde taky křehká, asi nejkřehčí. Třeba v tom, že si řeknu, že v ní nebudu dál pokračovat anebo ze mě úplně vymizí. Přijde mi to křehké, protože vůči všem ostatním vztahům to nějak jde řešit, ten druhý s tebou většinou nějak mluví. S tím Bohem je to jedno z takových nejsložitějších. Záleží na tom, že jsi s ním ochotná nějak mluvit a jak moc jsi ochotna s ním mluvit, že to nemůžeš brát jako jistotu. V tom je to tak křehké, ale zároveň svobodné. Pro mě je víra ted' taková věc, že vím, že Bůh je a je krásný, což ale neznamená, že to stejné si budu myslet i zítra. (Jolana)

Tendenci preferovat subjektivní náboženskou zkušenost spojuje Berger (1997) s „městským“ typem člověka, pro nějž je charakteristická vysoká míra svobody definovaná jako široká svoboda volby. Ve městech dochází ke splývání životních stylů, hodnot a názorů a lidé jsou zde nuceni se každodenně stýkat a konfrontovat vlastní názory a postoje s názory ostatních. V takových podmínkách vzniká pluralismus jako stav, kdy neexistuje skupina, jež by konstituovala společnost jako celek, a tím pádem ani skupina, která by svým členům mohla být všeobjímajícím společenstvím. Svoboda (a nutnost) volby daná těmito podmínkami pak nutně vede také k určitému stupni osamělosti jedince. U Terezy a Jolany, které opakovaně akcentovaly vlastní svobodu volby, se tato skutečnost projevovala pocity vykořenění, nejistoty a opakovaným hledáním smyslu života, a to i navzdory víre, kterou definovaly jako jednu z nejdůležitějších životních zkušeností.

Privatizace náboženského zážitku může vést i k oproštění se od konkrétní náboženské tradice a jí zavedených představ o Bohu. To se projevilo v odpovědi Jolany na otázku, zda hledá pouze věřícího životního partnera. Autenticita víry a představa Boha byla přímo podmíněna vlastním úsudkem a rozhodnutím:

Nevím, myslím si, že každý si o Bohu něco myslí, ale nenazývá ho zrovna takovým jako já. Když s nějakým člověkem mluvíš, bud'to v tom člověku je nebo ne - to se s ním domluvíš, podle toho, jestli ho prostě zajímají jenom naučené věci nebo o tom i sám přemýšlí... (Jolana)

Popsaný typ identifikace s křest’anstvím lze přirovnat $\mathrm{k}$ „humanistickému křest’anství“ tak, jak jej konceptualizovala Hervieu-Léger (1998), jež zahrnuje kombinaci kulturní a etické dimenze křest’anství. Je typické silně individualizovanou identifikací s křest’anskou tradicí a podle autorky je reprezentováno zejména intelektuály. Otázka křest’anské víry (v Boha, ve hřích, ve spásu, v božství Ježíše) může být v této perspektivě upozaděna nebo zcela opuštěna. U citovaných konverzačních partnerek se nedá mluvit o opuštění těchto náboženských představ, ale spíše o potřebě je interpretovat a validizovat individuálně. K určitému způsobu 
stvrzování víry může docházet také v konverzaci s jinými lidmi, kteří smýšlejí podobně. Jak ukazuje předešlá citace, je však jen těžké zachytit a popsat nějaké konkrétní náboženské představy ustavující se v průběhu takové konverzace, návaznost na určitou náboženskou tradici $\mathrm{v}$ tomto př́ípadě může být skutečně opouštěna a stvrzení víry (a její částečné sdílení) nahrazeno autenticitou prožitku a schopností individuálního náboženského hledání. V tomto světle viděno byla přirozenou součástí náboženského hledání těchto konverzačních partnerek i otevřenost $\mathrm{v}$ inspiraci z jiných náboženských směrů, než je křest’anství.

\section{Církev jako rodina - Bůh jako otec}

Čtyři komunikační partneři a partnerky $\mathrm{v}$ této kategorii kladli větší důraz na některé náboženské hodnoty, vymezení role Boha jako opory v běžných životních situacích a jeho vtažení do konkrétních denních problémů, a zdáli se být více zakotveni v křest'anské náboženské tradici. V̌̌ichni byli v křest’anské viŕre vychováváni a byli také dlouhodobě členy nějakého společenství věřících katolíků. Tř̌i z nich měli vysokoškolské vzdělání, jedna konverzační partnerka středoškolské. Dva se narodili a žili ve velkém městě, dva pocházeli z vesnice, avšak v době rozhovoru žili a pracovali ve městech. Nutnost privatizovat náboženskou zkušenost byla u některých z nich zřejmá, ale ne v takovém rozsahu jako u předešlých dvou konverzačních partnerek.

Náboženství tito mladí lidé definovali jako smysl života, směr, hloubku; zároveň jim však nedokázalo poskytnout zřejmé a jednoduché odpovědi. Naopak se u všech ukázalo, že víru lze chápat jako cestu, která je značně proměnlivá - osobní vztah $\mathrm{k}$ Bohu a názory na církev a její požadavky musí být vždy znovu upevňovány. Všichni tito komunikační partneři a partnerky vyrůstali $\mathrm{v}$ náboženské tradici katolické církve a jsou $\mathrm{v}$ nich silně zakořeněny $i$ tradiční křest'anské hodnoty (především v pojetí rodiny a partnerských vztahů). Svou zkušenost s dětstvím a dospíváním ve společenství veřících lidí ve městě popsala zejména Klára, která podobně jako další konverzační partneři a partnerky v této kategorii vyrůstala ve farnosti, kde se všichni věřící znají a děti dospívají společně. Tato společenství křest'anských rodin, ve kterých jsou děti socializovány a osvojují si určité normy, jsou do jisté míry omezeným a izolovaným prostorem. Existuje zde také specifická forma kontroly, vyplývající ze vzájemné blízkosti rodin, které jsou navíc svázané s určitým kostelem, respektive knězem jako primárním zdrojem určujícím tradici a morálku. Tato společenství křest’anů jsou v mnoha ohledech podobná tradičním komunitám a sítím vztahů, které se dnes objevují spíše na vesnicích.

Všichni věřící v této kategorii prošli v dospělosti procesem „vzdoru“ a odmítání některých katolických norem a hodnot, přestože je všichni v konečných důsledcích považovali za rozumné a smysluplné. Jeden konverzační partner mluvil o církevních normách týkajících se morálky v partnerském vztahu (společné soužití s dívkou před svatbou, které církev nepovoluje, mu znemožňovalo navštěvovat nedělní bohoslužby):

Máš nějaké doporučení, neřídiš se podle toho, tak narazíš, je to drsné. Když to pravidlo porušišs nebo přejdeš, tak se do toho dř́v nebo později zamotáš a dělá ti to víc problémů. To znamená, že mně ty pravidla hrozně ulehčuji život. Tím, že když je porušuji, vlastně si zavírám dveře. Sám sobě. (Míta) 
Víra je pro něj v životě na prvním místě, jak sám doslova řekl: „víra je pro mě život““. Zároveň ale přiznal, že se často chová jako ,pohan“, protože: ,s Bohem si povídám jen jako s automatem, když je špatně tak ano, jinak ne“. Bůh je v jeho životě chápán především jako útočiště, které vyhledává ve složitých životních situacích. Dodržování norem plynoucích z křest’anství mu zároveň pomáhá orientovat se v životě určitým jasně daným směrem: „Moje kariéra, to je mít ženu a sedm dětí - víc se nedá, protože mám řidičák skupiny $\mathrm{B}$, a to bych se musel naučit jezdit s autobusem. Takže sedm, ale to je deadline (smích).“

Podobně uvažovali i ostatní konverzační partneři a partnerky v této kategorii, pro které byla rodina v životě zásadní hodnotou. Jak to vyjádřil Patrik: „,nepokládám to, že jsem sám, za přirozený stav, myslím si, že nejsem povolaný k celibátu“. Přestože se jim z různých důvodů nedařilo naplňovat tento ideál, zároveň věřili v jeho budoucí naplnění: „...díky tomu, že mám víru, věŕím, že někde na mě čeká (partner - pozn. autorky) a nepodléhám depresím, melancholickým stavům, nebo že bych se nějak uklidňovala“ (Eva).

U všech byla patrná určitá „odevzdanost Bohu“ - smysl života je ve víře, že věci okolo nás mají vnitřní smysl, přestože my ho zrovna nevidíme. Náboženství zde plní funkci symbolického univerza: ,Zasazením vlastní identity do kontextu symbolického světa je však jednou provždy možné upevnit její legitimizaci (...), nejreálnější realita identity nemusí být legitimizována tím, že je jedinci v každém okamžiku známa. Pro její legitimizaci stačí, že je poznatelná“ (Berger, Luckmann 1999: 101). V kontextu křest’anského náboženství řečeno, není důležité jestli člověk ví, proč prochází určitou zkušeností a jaký je význam jeho života, podstatné je, že to ví Bůh. Je však zároveň zřejmé, že církev již není schopna nabízet nezpochybnitelnou nauku, její učení je jen jednou z mnoha nabídek „na trhu“ idejí, názorů a hodnot (Berger 1997). Ve výpovědích konverzačních partnerů a partnerek se to projevovalo potřebou náboženství v životě a rozpolceností nebo nejistotou toho, v co by měli věřit a co jim předkládá církevní autorita. Vztah k Bohu a přijímání církevní autority může do určité míry splývat, jak to vyplývá z výpovědi Kláry:

Je to hrozný propletenec, protože na jednu stranu je Bůh pomůcka, na druhou stranu hrozná kláda. Na svatbě jedněch kamarádů mě hrozně naštvalo, když farář při promluvě ř́kal: „To, že jste tady, že si slibujete věrnost na celý život, to není vůbec vaše zásluha, to je Boží dar.“ A já jsem v té lavici málem nadskočila a v duchu jsem nadskočila hodně, protože to mě naštvalo, protože pokud je láska nebo vztah Boží dar, tak ho někomu nedává a to absolutně nepřijímám. Absolutně ne. (Klára)

Nesouhlas s tvrzeními nebo postoji, které nabízí církevní autorita, se u Kláry projevil ve vyjednávání s Bohem a obviňování ho ze své situace (nemožnosti najít partnera).

Silný vztah k církvi se ukázal být u Patrika, který ji nazval „rodinou“, ve které je otcem Bůh a v návaznosti na tento vztah jsou všichni za sebe navzájem odpovědni, každý má v tomto společenství své místo a funkci, i kdyby to byla třeba „,̌̌erná ovce“ rodiny. ${ }^{15}$ I přes nesporné

15 V metafoře rodiny, která je v církvi používána, vidí Hervieu-Léger (2003, in Tichý 2006) známku procesu exkulturace církve, během kterého dochází k vyčerpání katolického systému kódů a zaplavení náboženské sféry jiným, nenáboženským programem socializace. Definice církve jako rodiny umožňuje udržet kontinuitu společenství, legitimizuje soudobý důraz na afektivní dimenzi vztahů, ale také aktivizuje laiky k převzetí odpovědnosti za církev, ve které ubývá kněží. 
sepětí $\mathrm{s}$ církví je $\mathrm{v}$ jeho životě a pojetí náboženství prioritou osobní vztah $\mathrm{k}$ Bohu, na základě kterého jsou zároveň vymezeny pomyslné hranice církevního společenství:

Církev je společenství lidí, kteří mají plus mínus podobný vztah s Bohem jako mám já. Pro mě je to důležité, včetně institucionálních věcí, které řeši spoustu dobrých a potřebných věcí. Je to taková rodina řekněme. (...) Víru prožívám jako osobní, hodně intenzívní vztah s Bohem, o tom to prostě celé je. (Patrik)

U těchto věŕících jsou $v$ různé míře zastoupeny všechny dimenze identifikace s náboženstvím, které vymezila Hervieu-Léger. V př́ipadě Patrika je možné mluvit o „emocionálním křest'anstvi'“, které zahrnuje především emocionální a společenskou dimenzi - přináležení k náboženské komunitě je aktivováno sdílením společných náboženských prožitků. V př́padě Míti o „patrimoniálním křest’anství“, ve kterém převládá kulturní a společenská dimenze. U Evy a Kláry o „humanitárním“, kdy je vyzdvihována především emocionální a etická dimenze křest'anství - obě ženy považovaly ve svém životě za podstatné věnovat se nějaké charitativní nebo dobrovolnické činnosti. Proces validizace vlastní náboženské zkušenosti probíhá různými způsoby, at’ už skrze spojení věrícího s určitým křest’anským společenstvím (většinou mladých lidí), přes sebe-stvrzování víry, až po určitou míru konformity s institucionální autoritou. Osobní víra prezentovaná jako vztah s Bohem, ${ }^{16}$ jež může anticipovat určitou míru distance od církve a potřebu vlastního výkladu náboženské zkušenosti, je však ve všech př́padech upřednostňována před př́slušností $\mathrm{k}$ církvi a loajalitě vůči církevní autoritě. Narozdíl od předešlé kategorie věřících se však osobní náboženský prožitek - vztah k Bohu - prolíná s přijímáním církevní autority, která více či méně určuje charakter tohoto vztahu (např́klad v určení toho, jaké jsou vlastnosti Boha, jak a proč jedná, jak správně definovat určité pojmy...).

\section{Sounáležitost s církví}

Identifikace $\mathrm{s}$ náboženstvím $\mathrm{u}$ konverzačních partnerů $\mathrm{v}$ této kategorii je pravděpodobně daná prostředím, ve kterém byli socializováni a ve kterém se pohybují i dnes, a jejich životním stylem. František a Pavel byli oba vychováváni v katolické tradici a víre a oba pochází z moravských vesnic, kde dodnes žijí. Oba mají také nižší vzdělání (jeden je středoškolák, druhý vyučený s maturitou) než ostatní osoby účastnící se výzkumu, což může mít vliv také na jejich způsob argumentace, vyjadřování a použivání určitého řečového kódu. Pokud ostatní mluvili o své viŕre pomocí abstraktnějších pojmů a své výpovědi doplňovali symbolickými př́í-

16 Je však třeba podotknout, že osobní vztah k Bohu, který zde prezentuji jako možný zdroj privatizace křest’anské náboženské zkušenosti, není v rozporu s církví, jejím učením a požadavky, které jsou na věřícího kladeny. Dnes masově rozšířený individualismus, který má sice své kořeny i v křest’anském pojetí individuální cesty ke spáse, je již považován za hodnotu sekularizovaného světa. Osobní spiritualita definovaná jako vztah člověka s Bohem začala být církví vyzdvihována ve druhé polovině 20. století. Podobně jako v případě přirovnání církve k rodině může jít o způsob přizpůsobení se hodnotám a požadavkům současné společnosti. Důraz na osobní vztah s Bohem však zároveň otevírá prostor vlastnímu, nezávislému výkladu náboženské zkušenosti a jako takový může vést až k opuštění náboženských představ daných církevní tradicí a učením. 
klady, František a Pavel se více odvolávali na konkrétní životní situace. Zvláště u Františka bylo patrné silné sepětí s tradičním vesnickým/venkovským prostředím, které se odráželo na jeho vnímání křest'anské víry. Zatímco Jolana s Terezou se vyslovovaly pomocí vysoce abstraktních a obecných pojmů, které referovaly k určitým ideálům, měla Františkova víra podobu silně zvnitřnělých postojů, názorů a norem, které on sám ani neměl potřebu vysvětlovat nábožensky. Náboženství je pro něj samožrejmá skutečnost, nedílně propojená s životem člověka, nad kterou nemá smysl více přemýšlet, což do jisté míry i sám reflektuje: „Kdybych k víře přišel sám, asi by byla živější, ale že jsem v ní vlastně vychovávaný odmala, tak je možná trochu vlažnější“ (František). Na otázku o důležitosti víry ve svém životě a o potřebě osobního vztahu s Bohem neuměl odpovědět a přímo řekl, že si míru dủležitosti své víry neuvědomuje. Ani Pavel př́liš nerozuměl otázce týkající se osobního vztahu s Bohem, později uvedl, že Bůh je pro něj opora v těžkých životních situacích: „Když je mi nejhůřr, tak vím, kam se obrátit a mám aspoň nějakou oporu trošku a zvládnu to přežít, když je mi zle (...) překonávám to nějak jinak než pitím..." (Pavel). Nepotřeba rozvíjet víru v podobě osobní náboženské zkušenosti u nich kontrastovala s přesvědčením o předávání katolické víry vlastním dětem. $\mathrm{Na}$ otázku, zda by pro něj byl přijatelný vztah s neveřící dívkou, odpověděl František takto: „Chtěl bych, aby byla věrící, ale není to podmínka. Hlavně kdyby byla neveřící, aby dovedla pochopit, že budu vychovávat děti v katolické viŕre“" (František).

Konformita v přijímání církevní autority se projevovala v silné míře identifikace s náboženskými normami a nedůležitosti je ověřovat nebo nad nimi více přemýšlet. Jejich porušení chápali jako přestupek vůči Bohu. Promýšlení vlastního života na základě každodenního rozpoznávání „dobra“ a „zla“ a povinnosti reflektovat svoje jednání jako správné nebo špatné by mělo být nedílnou součástí života věřícího křest’ana, pro kterého není závažný pouze současný okamžik, ale celý život směřující k Bohu. To se projevilo i u Františka, když přestoupení norem, které plynou z křest’anské tradice, označil za hřích nebo porušení zákona a byl si vědom toho, že svoje jednání zpětně racionalizuje na základě těchto norem a uvědomování si, co udělal špatně.

Životní styl Františka a Pavla byl charakteristický nízkou prostorovou mobilitou, odmítáním změny, snahou uspořádat si život podle tradičních (konzervativních) kritérií (například i v rodině a způsobu dělby rolí mezi mužem a ženou). Oba také žili se svými rodiči; ve Františkově prípadě byl způsob bydlení dán také zodpovědností za rodinný majetek (dům, zahrada, pole, vinohrad) a společnou starostí rodiny o něj. Oba byli členy nějakého křest’anského společenství (František zpíval v kostelním sboru).

Na vesnicích (zejména pokud jde o venkovské oblasti jižní Moravy, odkud pochází oba konverzační partneři) je pozice církve tradičně silnější než ve městech, kde dochází ke splývání životních stylů, hodnot a názorů a $\mathrm{k}$ jejich následné relativizaci. $\mathrm{V}$ městském prostředí může být proto nutností každý den znovu ospravedlňovat a interpretovat své postoje a názory. Spojení s určitým místem, půdou, komunitou a rodinou na vesnici může však být v některých př́ípadech stále velmi silné - určuje způsob života člověka a jeho identitu. Rodina zde hraje důležitou roli, protože je prostorem předávání materiální i symbolické tradice, která ukotvuje tento způsob života. František a Pavel sice studovali mimo své bydliště, nicméně i v této době se domů pravidelně vraceli. Jejich náboženská zkušenost má spiše podobu sounáležitosti s náboženskou organizací, jejími hodnotami a normami, neobjevuje se u nich potřeba privatizovat 
náboženský zážitek. Podobně se u nich neprojevila ani nutnost prověřovat normy dané církví. Náboženské hodnoty mohou být $\mathrm{v}$ tomto prostředí smyslem samy o sobě, protože pomáhají vytvářet takovou biografii člověka, která je $\mathrm{v}$ těchto podmínkách pochopitelná a přijatelná a kterou není potřeba ospravedlňovat vůči okolnímu světu, a tím pádem ani před sebou samotným. Pro oba konverzační partnery bylo životní prioritou založení rodiny a pokračování ve způsobu života svých rodičů: „Chtěl bych tu být pro rodinu, chtěl bych postavit dům - nebydlet doma s rodiči“" (František). Př́ícinou absence partnerského vztahu mohla být v jejich př́padě právě nízká mobilita a málo př́ležitostí seznámit se s novými lidmi.

Tento typ identifikace s křest’anskou vírou se bližźi „patrimoniálnímu křest’anstvi““, do nějž Hervieu-Léger zahrnuje orientaci na církev, vědomí přináležení $\mathrm{k}$ ní a vlastnictví kulturního dědictví církve. Radikální vymezení mezi „my“ a „oni“, které může být součástí tohoto typu identifikace, však nebylo $\mathrm{v}$ př́padě zmíněných konverzačních partnerů zřejmé, i vzhledem $\mathrm{k}$ tomu, že necítili potřebu se nějak radikálně nebo aktivně vyhraňovat vůči okolí (v př́ipadě Františka), a pokud ano, tak ,pouze“ ve formě osobního odmítnutí a stigmatizace životního stylu a norem, které odporují křest’anským představám (v př́ipadě Pavla).

\section{Závěr}

Privatizace a deprivatizace náboženství jsou chápány jako dvě protichůdné vývojové tendence: zejména velká náboženství, která dříve plnila funkci „posvátného baldachýnu“17 a mocí a vlivem byla schopná předávat svým následovníkủm nezpochybnitelnou nauku, reagují na snižení a oslabení své autority snahou dostat se zpět do veřejného prostoru, znovu-posílit význam některých náboženských norem a hodnot. Podle Casanovy (2005) to velmi pravděpodobně budou ta náboženství, která se sice zřekla své identity jako donucovací instituce, ale nezřekla se své identity jako „církve“ jak ve smyslu mravního společenství, tak společenství univerzalistického nároku na spásu.

Úsilí církví a náboženských organizací rozšřřit náboženskou sféru vlivu může probíhat paralelně ve dvou směrech - jednak ven z náboženské organizace, směrem k sekularizované společnosti, ale také dovnitř, $\mathrm{s}$ cílem posílit církevní autoritu i v řadách samotných věrících ${ }^{18}$. Jedinec, jenž vyznává určitou víru (v tomto př́ípadě rímskokatolickou), se může dostávat pod pomyslný dvojí tlak: v sekularizované společnosti jsou prosazovány často opačné hodnoty, než na jaké tradičně klade důraz římskokatolická církev.

Výzkum, jehož některé závěry zde byly prezentovány, sledoval tuto rozporuplnost v biografiích a životních postojích mladých, dosud nesezdaných lidí bez partnera, pro něž se i u nás vžil anglický název singles. Životní styl singles je spojován s existencí alternativních, tedy na dlouhodobější závazky a rodinu neorientovaných partnerských vztahů. Mladí katolíci, se kterými jsem vedla rozhovory, se však v tomto směru zdáli být konformní s hodnotami

17 Tuto metaforu použil Berger (1967) k vyjádření představy náboženství jako vše zastřešujícího zákona (nomos), integrujícího celou společnost.

18 Berger (1997) mluví o vytváření tzv. kognitivni hradby - církev se uzavírá do sebe, vytváří si hradby, které ji chrání před okolním světem, zdůrazňuje ta témata, kterými se od okolního světa odlišuje a zároveň prezentuje vlastní hodnoty jako obecně platná pravidla. 
katolické církve, svůj status single nechápali jako možnost otevřenosti k alternativním vztahům. Žádoucí partnerský vztah pro ně byl charakteristický závazností, dlouhodobostí a perspektivou založení rodiny, která byla $\mathrm{v}$ jejich životě prioritou. Snaha uspořádat si život v podobě tradičního rodinného modelu co nejrychleji však byla typičtější pro ty konverzační partnery a partnerky, kteří zároveň vyjadřovali větší propojenost s církví a jejími normami. Náboženství hrálo v jejich životě častěji roli opory a jistoty, nebo také garanta určitého předem daného způsobu života. U některých z nich se však projevoval rozpor mezi normami, které by měli jako katoličtí věřící dodržovat, a realitou života $\mathrm{v}$ současné společnosti (např́ílad $\mathrm{v}$ podobě neschopnosti vytrvat $\mathrm{v}$ partnerském vztahu). V oblasti identifikace s náboženstvím byl tento rozpor popsán jako nedůvěra $\mathrm{k}$ církvi a jejím hodnotám, částečná distance vůči nim nebo preference osobního vztahu s Bohem jako intimního a individuálního prostoru naplňování náboženských představ.

Naproti tomu dvě konverzační partnerky, které ve svém životě nepovažovaly církevní normy za závazné, hodnotily náboženství především jako zdroj svobody, pravdy, rovnováhy sama se sebou. Takto pojímané náboženství je však zároveň neochraňovalo před pocity nejistoty, vykořeněnosti nebo ztráty smyslu v životě. Směřování a vývoj své biografie chápaly jako svůj vlastní, individuální projekt, který nemusí být veden v intencích současné společnosti (jako snaha získat dobré postavení na pracovním trhu) nebo podle převažujících církevních představ (jako založení rodiny a starost o ni). Náboženství pro ně nebylo garancí určitého způsobu života. Jejich identifikace s křest’anstvím v podobě osobního vztahu s Bohem jim dávala jistotu v možnosti volit si svůj vlastní, individuální životní styl a představy o něm. Vliv sekularizované společnosti, respektive privatizace náboženství je na postoji těchto žen zřejmý právě ve zdůraznění nutnosti volby, nezávislosti, odmítání vnějších autorit.

K rozdělení účastníků výzkumu do tří typů jsem použila konceptuální rámec identifikace s náboženstvím tak, jak ho vytvořila Hervieu-Léger (1998). Zatímco v jejím pojetí nemusí jednotlivé typy identifikace s náboženstvím nutně znamenat také př́slušnost $\mathrm{k}$ náboženské organizaci, $\mathrm{v}$ mém výzkumu šlo pouze o věřící katolíky, kteří se $\mathrm{v}$ době uskutečnění rozhovorů zároveň aktivně a pravidelně účastnili života církve. Vazba ke křest’anství se u nich projevovala dvěma částečně se překrývajícími způsoby (nebo větší či menší preferencí pouze jednoho $\mathrm{z}$ těchto způsobů): přijetím církve jako autoritativní organizace a osobním vztahem $\mathrm{k}$ Bohu, jenž může skýtat naopak možnost distance od církve a vytvoření paralelního soukromého náboženského prostoru. Tři typy, které jsem $\mathrm{v}$ textu prezentovala, jistě nevyčerpávají možnou další škálu identifikace s konkrétním náboženstvím, spíše ukazují, jakým směrem a způsobem může i uvnitř deprivatizovaného náboženství docházet $\mathrm{k}$ jeho privatizaci. Ve statistikách by se tito lidé velmi pravděpodobně zahrnuli do kolonky „věřící, praktikující katolík“, avšak při bližším zkoumání je i tato kategorie nejednoznačná a vnitřně pluralizovaná. Vzhledem k tomu, že výzkum nebyl primárně zaměřen pouze na náboženské biografie zkoumaných osob, ale na (nejen) náboženské zkušenosti z jednoho časového období, je také velmi pravděpodobné, že jejich náboženské preference nebo způsob stvrzování víry se mohou v průběhu času měnit tak, jak to v jiném výzkumu ukázala napríklad Spalová (2004). 


\section{Literatura}

BARTOŠOVÁ, Michaela. Věřící singles ve světle měnících se forem praktikování víry a individualizace ve sféře náboženství. Gender-rovné přiležitosti-výzkum, 2006, č. 1, s. 15-19. ISSN 1213-0028.

BAWIN-LEGROSS, Bernadette. Intimacy and the New Sentimental Order. Current Sociology, 2004, č. 2, s. 241-250. ISSN 0011-3921.

BECK, Ulrich. Risk Society: Towards a New Modernity. 1. vyd. London : Sage, 1992. 272 s. ISBN 0-80398-346-8.

BECK, Ulrich ; BECK-GERNSHEIM, Elisabeth. The Normal Chaos of Love. Oxford : Polity Press. 1995, 240 s. ISBN 0-74561-382-9.

BERGER, Peter L. The Sacred Canopy: Elements of a Sociological Theory of Religion. New York : Doubleday, 1967. 240 s. ISBN 0-3850-7305-4

BERGER, Peter L. Vzdálená sláva. Hledání viry ve věku lehkověrnosti. 1. vyd. Brno : Barrister\&Principal, 1997. 188 s. ISBN 80-85947-18-8.

BERGER, Peter L. ; LUCKMANN, Thomas. Sociální konstrukce reality. 1. vyd. Brno : CDK, 1999. 216 s. ISBN 80-85959-46-1.

BRUCE, Steve. God is Dead: Secularization in the West. Malden, MA : Blackwell Pub., 2002. 269 s. ISBN 0-63123-275-3.

CASANOVA, Jose. Public Religions in the Modern World. Chicago - London : University of Chicago Press, 1994. 330 s. ISBN 0-22609-535-5.

CASANOVA, Jose. Naděje a úskalí veřejného náboženství. Srovnání mezi východní a západní Evropou. In HANUŠ, J. ; VYBÍRAL, J. (eds.) Evropa a její duchovní tvár̆: esejekomentáré-diskuse. 1. vyd. Brno : Centrum pro studium demokracie a kultury, 2005, s. 83-104. ISBN 80-7325-071-3.

DAVIE, Grace. Religion in Britain Since 1945: Believing Without Belonging. Malden : Blackwell Publishing, 1994. 240 s. ISBN 0-63118-444-9.

DAVIE, Grace. New Approaches in the Sociology of Religion: A Western Perspective. Social Compass, 2004, č. 1, s. 73-84. ISSN 0037-7686.

DOBBELAERE, Karel. Towards an integrated perspective of the processes related to the descriptive concept of secularization. Sociology of Religion, 1999, č. 3, s. 229-247. ISSN 1069-4404.

GIDDENS, Anthony. The Transformation of Intimacy. Sexuality, Love and Eroticism in Modern Societies. 1. vyd. Cambridge : Polity Press, 1992. 216 s. ISBN 0-80472-214-5.

HAMPLOVÁ, Dana. Náboženství a nadprirozeno ve společnosti. Mezinárodní srovnání na základě empirického výzkumu ISSP. Sociologické texty/Sociological Papers 3. 1. vyd. Praha : Sociologický ústav AV ČR, 2000. 60 s. ISBN 80-7330-033-8.

HEATH, Sue ; CLEAVER, Elizabeth. Young, Free and Single? Twenty-somethings and Household Change. New York: Palgrave, 2003. 225 s. ISBN 1-40390-124.

HERVIEU-LÉGER, Danièle. Catholicisme, la fin d'un monde. Paris : Bayard, 2003. 333 s. ISBN 2-22731-707-8.

HERVIEU-LÉGER, Danièle. Le Pelerin et le Converti: La Religion en Mouvement. Paris : Flammarion, 1999. 300 s. ISBN 2-08080-017-5. 
HERVIEU-LÉGER, Danièle. The Transmission and Formation of Socioreligious Identities in Modernity. International Sociology, 1998, č. 2, s. 213-228. ISSN 0268-5809.

KAA, Dirk van de. Europe's Second Demographic Transition. Population Bulletin, 1987, č. 1. ISSN 0021-7604.

KEPEL, Gilles. Boží pomsta. Křest'ané, židé a muslimové znovu dobývají svět. 1. vyd. Brno : Atlantis, 1996. 184 s. ISBN 80-7108-120-5.

KUCHǍ̌OVÁ, Věra ; ZAMYKALOVÁ, Lenka. Předpoklady sňatkového a rodinného chování mladé generace. Sociální politika, 2000, č. 2, s. 14-16. ISSN 0049-0962.

LUCKMANN, Thomas. The Invisible Religion. New York : Macmillan, 1967. ISBN 0-02576-700-3.

LUŽNÝ, Dušan. Sekularizace, individualizace a veřejné náboženství. In HANUŠ, J. ; VYBÍRAL, J. (eds.) Evropa a její duchovni tvářr: eseje-komentáře-diskuse. Brno : Centrum pro studium demokracie a kultury, 2005, s. 109-111. ISBN 80-7325-071-3.

NEŠPOR, Zdeněk R. Ústřední vývojové trendy současné české religiozity. In NEŠPOR, Z. R. (ed.) Jaká víra? Současná česká religiozita/spiritualita v pohledu kvalitativní sociologie náboženství. Praha : Sociologický ústav AV ČR, 2004, s. 21-37. ISBN 80-7330-061-3.

RABUŠIC, Ladislav. Kde ty všechny děti jsou? 1. vyd. Praha: Sociologické nakladatelství, 2001. 265 s. ISBN 80-86429-016.

SINGLY, Francois. Sociologie současné rodiny. 1. vyd. Praha : Portál, 1999. 128 s. ISBN 80-7178-249-1.

SPALOVÁ, Barbora. Zbožnost v režimech pravdy. Biograf [online]. 2004, roč. 33 [cit. 2008-04-03]. 2004. Dostupný na: http://www.biograf.org/clanky/clanek.php?clanek= v3303. ISSN 1211-5770.

STRAUSS, Anselm ; CORBIN, Juliet. Grounded Theory Methodology: An Overview. In DENZIN, N. K. ; LINCOLN, Y. S. (eds.) Strategies of Qualitative Inquiry. 1. vyd. Thousands Oaks, London, New Dehli : Sage, 1998. s. 158-183. ISBN 0-76192-691-7.

STRAUSS, Anselm ; CORBIN, Juliet. Základy kvalitativního výzkumu. 1. vyd. Boskovice : Albert, 1999. 196 s. ISBN 80-8583-460-X.

TICHÝ, Radek. Katolicismus: privatizace i deprivatizace náboženství pod jednou střechou. Socioweb [online], 2004, č. 8 [cit. 2008-24-03].

Dostupný z: http://www.socioweb.cz/index.php?disp= temata\&shw=190\&lst=121. ISSN 1214-1720.

TICHÝ, Radek. Náboženství v pohybu. Biograf [online], 2006, č. 39 [cit. 2008-24-03]. Dostupný z: http://www.biograf.org/clanky/clanek.php?clanek=3908. ISSN 1211-5770.

TOMÁŠEK, Marcel. Singles a jejich vztahy; kvalitativní pohled na nesezdané a nekohabitující jednotlivce v České republice. Sociologický časopis, 2006, č. 1, s. 81-105. ISSN 0038-0288.

\section{Autorka}

Michaela Bartošová je odbornou pracovnicí Institutu pro výzkum reprodukce a integrace společnosti při Fakultě sociálních studií Masarykovy univerzity v Brně. Zde také studuje doktorský studijní program na katedře sociologie. Kromě sociologie náboženství patří k jejím odborným zájmům především sociologie rodiny, konkrétně problematika časování mateřství, bezdětnost a singles. Kontakt: bartosov@fss.muni.cz 